\section{'Micro-Gold' Miniature Dwarf Tomato}

\author{
J.W. Scott and B.K. Harbaugh \\ Gulf Coast Research and Education Center, 5007 60th Street East, University \\ of Florida, Bradenton, FL 34203
}

\section{Additional index words. Lycopersicon esculentum}

'Micro-Gold' is a miniature dwarf tomato (Lycopersicon esculentum Mill.) with goldcolored fruit. It is a companion to 'MicroTom' (Scott and Harbaugh, 1989), which has been the smallest tomato cultivar released to date. Like 'Micro-Tom', 'Micro-Gold' is being released as a tomato that can be grown singly in small pots $(13 \mathrm{~cm}$ in diameter; 1 -liter volume), as three plants in hanging pots (15 $\mathrm{cm}$ in diameter; 1.8-liter volume), or more plants in larger hanging pots. It is also ideal for window boxes or garden borders because the plant canopy diameter is only $19 \mathrm{~cm}$ (spring) to $26 \mathrm{~cm}$ (fall) (Table 1). 'Micro-Gold' combines ornamental aspects of a well-proportioned, diminutive, tomato plant with a mildtasting fruit that can be eaten. The small plant size makes it ideal for commercial growing, shipping, and retail selling.

\section{Origin}

'Micro-Gold', tested as Fla. 7564, was increased in the $\mathrm{F}_{9}$ generation following priof miniature dwarf breeding lines Fla. $7188 x$ 874379-1 (Fig. 1). Fla. 7188 (red fruit) was used because of its excellent fruit set, and 874379-1 was used for its gold fruit color and retention of green foliage when fruit are malines (Ohio 4014-4 and Ohio 4013-3) in their background, which provided the miniature plant, leaf, and fruit sizes. The dwarf character of the parent lines was derived from 'Florida Petite' (Augustine et al., 1981b) or 'Florida Basket' (Augustine et al., 1981a), which were earlier dwarf tomato releases from the Univ. of Florida. The gold fruit color originated from PI 205046.

\section{Description}

'Micro-Gold' is a short, compact, dwarf plant that is slightly wider and less prostrate than that of 'Micro-Tom'. However, 'Micro-

Received for publication 21 Jan. 1995. Accepted for publication 17 Mar. 1995. Florida Agricultural Expt. Station Journal Series no. R-03924. We thank Nancy West, Karen Pearce, and Jan Watson for their excellent technical support. The cost of publishing this paper was defrayed in part by the payment of page charges. Under postal regulations, this paper therefore must be hereby marked advertisement solely to indicate this fact. marily single-plant selections from the cross ture. Both parents have closely related Ohio
Gold' plants are shorter than 'Yellow Canary' plants - the smallest yellow-fruited cultivar commercially available (Table 1, Fig. 2). 'Micro-Gold' is well suited to growing in small containers because its small plant size is genetically controlled. Non-miniature dwarf cultivars tend to overgrow small containers, and their plant size is restricted by the container size. The foliage of 'Micro-Gold' remains green even as fruit ripen. Foliage chlorosis and deterioration has been a problem with many yellow-fruited, dwarf breeding lines. Leaves are smaller than those of typical dwarf cultivars but slightly larger than those of 'MicroTom'.

'Micro-Gold' fruit have jointed pedicels; they are similar or slightly larger in size than those of 'Micro-Tom' and are similar or smaller in size than those of Fla. 7565 (Table 1). 'Yellow Canary' fruit were always larger than those of the other three cultigens. 'MicroGold' produced about the same number or fewer fruit per pot as 'Yellow Canary' and an equal number or fewer than 'Micro-Tom' (Table 1). Fruit shoulders are uniform green $(u)$ and ripen to a golden color due to an undetermined gene for yellow flesh color $(r$ or a similar gene) and yellow epidermis $(y+)$. In contrast, 'Yellow Canary' fruit remain more
Table 1. Evaluation of foliar and fruit characteristics of 'Micro-Gold', Fla-7565, 'Micro-Tom', and 'Yellow Canary' tomato cultigens grown as single plants in pots $(13 \mathrm{~cm}$ in diameter) or three plants in hanging pots $\left(15 \mathrm{~cm}\right.$ in diameter) under greenhouse conditions in Spring and Fall 1993 in Bradenton, Fla. ${ }^{2}$

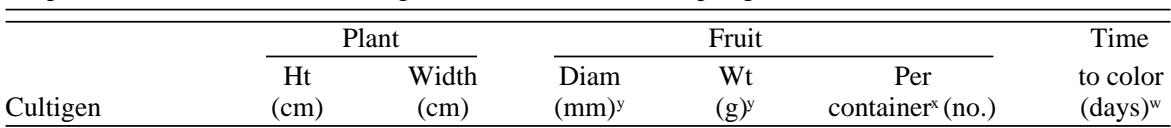

\begin{tabular}{|c|c|c|c|c|c|c|}
\hline \multirow{2}{*}{\multicolumn{7}{|c|}{ ngle plant per $13-\mathrm{cm}$ pot }} \\
\hline \multirow{2}{*}{\multicolumn{7}{|c|}{$\begin{array}{l}\text { Spring } \\
\text { Micro-Gold }\end{array}$}} \\
\hline & & & & & & \\
\hline Fla-7565 & $10 \mathrm{~b}$ & $21 \mathrm{~b}$ & $25 \mathrm{~b}$ & $9.0 \mathrm{~b}$ & 33 & $90 \mathrm{c}$ \\
\hline Micro-Tom & $10 \mathrm{~b}$ & $25 \mathrm{a}$ & $22 \mathrm{~d}$ & $6.2 \mathrm{~d}$ & 42 & $92 \mathrm{c}$ \\
\hline Yellow Canary & $22 \mathrm{a}$ & $25 \mathrm{a}$ & $29 \mathrm{a}$ & $13.6 \mathrm{a}$ & $32^{\mathrm{Ns}}$ & $103 \mathrm{a}$ \\
\hline \multicolumn{7}{|l|}{ Fall } \\
\hline Micro-Gold & $25 \mathrm{ab}$ & 19 & $27 \mathrm{~b}$ & $9.8 \mathrm{~b}$ & $19 \mathrm{~b}$ & $74 \mathrm{a}$ \\
\hline Fla-7565 & $21 \mathrm{c}$ & 20 & $27 \mathrm{~b}$ & $10.3 \mathrm{~b}$ & $20 \mathrm{~b}$ & $69 \mathrm{~b}$ \\
\hline Micro-Tom & $23 \mathrm{bc}$ & 22 & $25 \mathrm{c}$ & $7.5 \mathrm{c}$ & $27 \mathrm{a}$ & $73 \mathrm{a}$ \\
\hline Yellow Canary & $27 \mathrm{a}$ & $22^{\mathrm{Ns}}$ & $29 \mathrm{a}$ & $14.3 \mathrm{a}$ & $17 \mathrm{~b}$ & $74 \mathrm{a}$ \\
\hline \multicolumn{7}{|c|}{ Three plants per $15-\mathrm{cm}$ hanging pot } \\
\hline \multicolumn{7}{|l|}{ Spring } \\
\hline Micro-Gold & $15 \mathrm{~b}$ & $32 \mathrm{a}$ & $24 \mathrm{c}$ & $9.2 \mathrm{bc}$ & $57 \mathrm{a}$ & $95 \mathrm{~b}$ \\
\hline Fla-7565 & $10 \mathrm{c}$ & $26 \mathrm{~b}$ & $27 \mathrm{~b}$ & $10.4 \mathrm{~b}$ & $42 \mathrm{~b}$ & $87 \mathrm{~d}$ \\
\hline Micro-Tom & $9 \mathrm{c}$ & $28 \mathrm{~b}$ & $25 \mathrm{c}$ & $7.0 \mathrm{~d}$ & $62 \mathrm{a}$ & $91 \mathrm{c}$ \\
\hline Yellow Canary & $26 \mathrm{a}$ & $29 \mathrm{ab}$ & $31 \mathrm{a}$ & $14.4 \mathrm{a}$ & $37 \mathrm{~b}$ & $103 \mathrm{a}$ \\
\hline \multicolumn{7}{|l|}{ Fall } \\
\hline Micro-Gold & $24 \mathrm{~b}$ & 28 & $26 \mathrm{bc}$ & $9.2 \mathrm{bc}$ & $29 \mathrm{c}$ & $75 \mathrm{a}$ \\
\hline Fla. 7565 & $21 \mathrm{~b}$ & 26 & $27 \mathrm{~b}$ & $10.8 \mathrm{~b}$ & $38 \mathrm{~b}$ & $67 \mathrm{c}$ \\
\hline Micro-Tom & $20 \mathrm{~b}$ & 28 & $25 \mathrm{c}$ & $8.2 \mathrm{c}$ & $51 \mathrm{a}$ & $71 \mathrm{~b}$ \\
\hline Yellow Canary & $33 \mathrm{a}$ & $27^{\mathrm{ss}}$ & $30 \mathrm{a}$ & $14.6 \mathrm{a}$ & $26 \mathrm{c}$ & $74 \mathrm{ab}$ \\
\hline
\end{tabular}

${ }^{2}$ Seeding dates 14 Jan. (spring) and 24 Aug. 1993 (fall).

${ }^{y}$ Average fruit diameter and weight of the first five fruit to ripen per plant.

${ }^{x}$ Number of green and ripe fruit $\approx 2$ weeks after first fruit color.

"Days from seeding to first appearance of gold ('Micro-Gold' and Fla. 7565), yellow ('Yellow Canary'), or red ('Micro-Tom') fruit.

"Mean separation within columns for each season by Duncan's multiple range test significant or nonsignificant (NS) at $P \leq 0.05$.

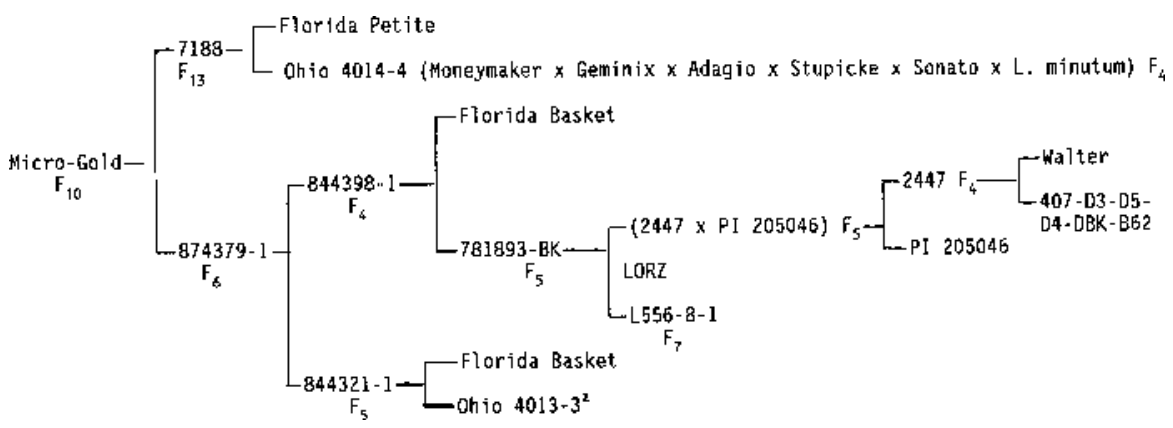

Fig. 1. Pedigree of 'Micro-Gold'.

${ }^{\mathrm{z}}$ Same parents as Ohio 4014-4. 


\section{Cultivar \& Germplasm Releases}
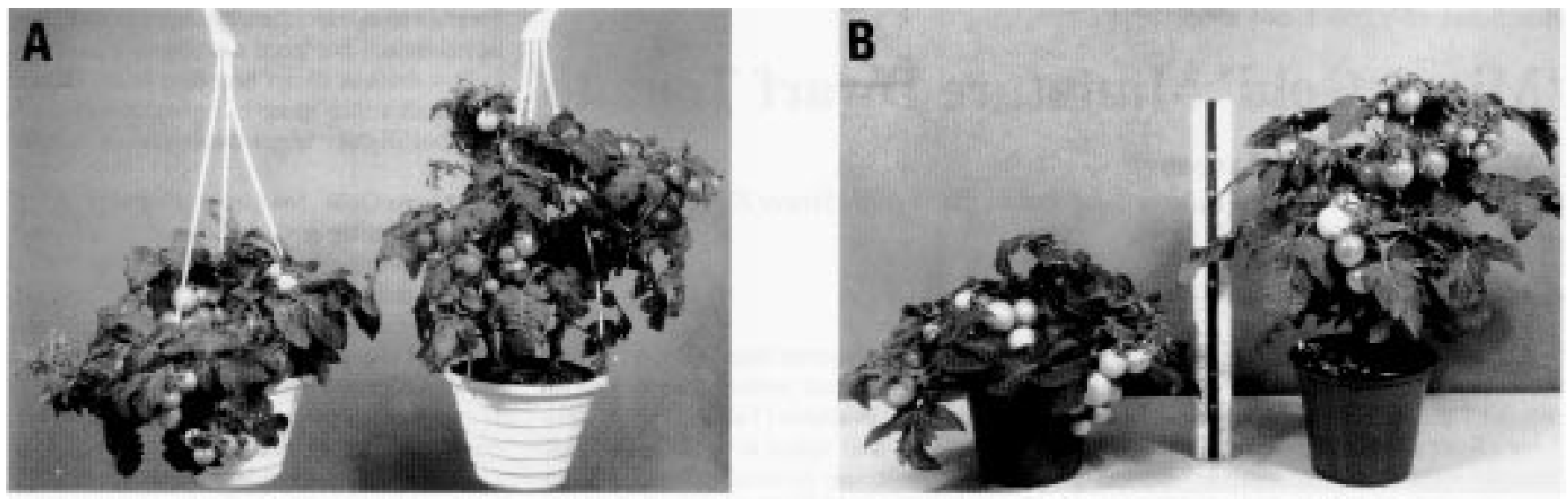

Fig. 2. (left) 'Micro-Gold' and (right) 'Yellow Canary' grown in (A) hanging pots $15 \mathrm{~cm}$ in diameter (1.8 liter) with three plants per hanging pot and (B) pots 13 $\mathrm{cm}$ in diameter (1 liter) with one plant per pot.

yellow because the epidermis is colorless ( $y$ ). Time from seeding to ripe fruit color of 'Micro-Gold' was 74 days in the fall and 95 to 96 days in the spring (Table 1). Under some conditions, older fruit of 'Micro-Gold' can appear glassy or translucent. Fruit should be consumed before this stage, or they will be mushy. 'Micro-Gold' fruit have a mild, tomato-like flavor that is less acidic than 'Micro-Tom' fruit. However, no significant differences in citric acid or soluble solids : citric acids ratio were determined between these two cultivars in a Spring 1993 test (Table 2). 'Yellow Canary' is slightly sweeter than 'Micro-Gold'; in Spring 1993, this characteristic may have been reflected in the higher soluble solids : citric acid ratio of 'Yellow Canary' because it had a lower soluble solids concentration than 'Micro-Gold' (Table 2).

'Micro-Gold' is resistant to fusarium wilt race 1 [Fusarium oxysporum Schlecht. f.sp. lycopersici (Sacc.) Snyder and Hansen] and gray leafspot (Stemphyllium solani Weber). Fruit have a high level of resistance to radial and concentric cracking, rain check, blossomend rot, and ripening disorders, such as blotchy ripening and graywall.

\section{Seed availability}

'Micro-Gold' is an open-pollinated (pure line) release. Distribution for commercial seed production purposes is handled through the Florida Foundation Seed Producers, P.O. Box 309, Greenwood, FL 32443.

\section{Literature Cited}

Augustine, J.J., B.K. Harbaugh, and J.P.Crill. 1981a. Florida Basket: A dwarf tomato for hanging
Table 2. Soluble solids (SSC) and citric acid concentrations and SSC : citric acid ratio for dwarf tomato cultigens grown in the field at Bradenton, Fla., in Spring 1993.

\begin{tabular}{lccc}
\hline \hline Cultigen & $\begin{array}{c}\text { SSC } \\
(\%)\end{array}$ & $\begin{array}{c}\text { Citric } \\
\text { acid }(\%)\end{array}$ & $\begin{array}{c}\text { SSC : } \\
\text { acids }\end{array}$ \\
\hline Micro-Gold & $5.37 \mathrm{a}^{\mathrm{z}}$ & $0.650 \mathrm{a}$ & $8.28 \mathrm{bc}$ \\
Fla. 7565 & $4.40 \mathrm{~b}$ & $0.498 \mathrm{~b}$ & $8.83 \mathrm{ab}$ \\
Micro-Tom & $4.33 \mathrm{bc}$ & $0.657 \mathrm{a}$ & $6.58 \mathrm{c}$ \\
Yellow Canary & $3.67 \mathrm{c}$ & $0.361 \mathrm{c}$ & $10.24 \mathrm{a}$ \\
\hline
\end{tabular}

${ }^{2}$ Mean separation within columns by Duncan's multiple range test at $P \leq 0.05$.

baskets. Florida Agr. Expt. Sta. Circ. S-283.

Augustine, J.J., B.K. Harbaugh, and J.P. Crill. 1981b. Florida Petite: An extremely dwarf tomato for window sill gardens. Florida Agr. Expt. Sta. Circ. S-285.

Scott, J.W. and B.K. Harbaugh. 1989. Micro-Tom: A miniature dwarf tomato. Florida Agr. Expt. Sta. Circ. S-370. 